\title{
Erratum to: Apperception, Self-Consciousness, and Self-Knowledge in Kant
}

\section{Dennis Schulting}

Erratum to:

Chapter 7 in: M. C. Altman (ed.), The Palgrave Kant Handbook, Palgrave Handbooks in German Idealism, https://doi.org/10.1057/ 978-1-137-54656-2_7

The original version of Chapter 7 was inadvertently published without a symbol $\phi$ on page 149 . The chapter has been updated.

The updated online version of this chapter can be found at https://doi.org/10.1057/978-1-137-54656-2_7

(C) The Author(s) 2018

M. C. Altman (ed.), The Palgrave Kant Handbook, Palgrave Handbooks

in German Idealism, https://doi.org/10.1057/978-1-137-54656-2_36 